\title{
Technological Pedagogical and Content Knowledge of ESP Teachers in Blended Learning Format
}

\author{
https://doi.org/10.3991/ijet.v15i06.11490 \\ Dodi Mulyadi ( $\left.{ }^{\varpi}\right)$ Testiana Deni Wijayatingsih, Riana Eka Budiastuti, \\ Muhimatul Ifadah, Siti Aimah \\ Universitas Muhammadiyah Semarang, Semarang, Indonesia \\ dodiaunimus.ac.id
}

\begin{abstract}
The onslaught of technology in language learning necessitates ESP teachers to enhance their teaching quality by integrating technology, pedagogy, and subject matters. To this end, the present research was an effort to discern Technological Pedagogical and Content Knowledge (TPACK) of ESP teachers in a blended learning format. A modified online survey comprising 28 closed-ended questions were administered to 70 ESP instructors of nursing purposes from 35 Universities in Indonesia. The data were analyzed statistically to be depicted in descriptive statistics (percentages of frequencies, means, and standard deviations). As a result, three out of four TPACK subdomains, including technological content knowledge (TCK), and Technological Pedagogical Knowledge (TPK), Technological Pedagogical and Content Knowledge (TPACK) have been mastered by most ESP teachers. However, they have to improve their pedagogical content knowledge (PCK). The current research also contributes some empirical insights into how ESP teachers can construct the overarching ESP instruction in English for nursing purposes integrating TPACK.
\end{abstract}

Keywords-ESP teachers, Technological Pedagogical and Content Knowledge (TPACK), Blended Learning.

\section{Introduction}

Concerning the significance of English in multifarious field and disciplines, the needs for teaching ESP is apparent. However, ESP teachers have responsibilities to master not only linguistics and pedagogical knowledge but also the subject matter or content of the course [1]. Therefore, they encounter challenges to well integrate language pedagogy with ESP materials in order to make students have real-world communicative competence for their professional careers.

The onslaught of information and communications technology (ICT) development makes Technology in Language Learning become an indispensable part of coping with the challenges in teaching ESP. It necessities ESP teachers to integrate technology as learning media, pedagogy, and contents. The utilization of technology in pedagogical methodologies help teachers to design innovative learning activities and me- 
dia efficiently [2]. Furthermore, the integration of technology can be effective in educational context if the educators deem the attributes and affordances align with the subject content and associated theories of learning and teaching practices [3]. Thus, the utilization of technology that is fit to the learning goals, attributes, and affordances significantly contribute to the development of education, particularly in Indonesian higher institutions.

The role of the teachers wherein conventional learning the teacher is the only source of learning, but nowadays, their role in learning is as a facilitator. They have the responsibilities to empower students to be autonomous and active learners. One approach that combines active learning and technology is blended learning (BL), which is also called hybrid online learning [4], and characterized by the rapid development of e-learning [5]. BL has been deemed as an effective learning approach to combine strengths between face-to-face instruction and online one to undertake worthwhile learning goals [6, 7], and provide an educational opportunity which empowers learners to have a better learning process.

Some pre-condition issues such as institutional support, infrastructural readiness, content readiness, instructor readiness, learner readiness should be contemplated in implementing BL [8]. The previous studies of BL focusing on learners' readiness have been conducted, but little research concerning the readiness of educators' perspectives [9-16]. Thus, one of the issues that should be taken into account is the instructor or teacher readiness dealing with the ability to create online discussion session, willingness to make student engagements, the capability to encourage distance collaborative learning, and ability to design website course or develop learning management system [8]. The teachers' deep understanding of how to befittingly incorporate technology into their teaching enacts the important role to apply BL in teaching ESP.

In English language teaching (ELT) context, BL commonly addresses to integrate face-to-face instruction with technology involving both online and offline activities/ materials [17]. Therefore, the English teachers should have knowledge in integrating technologies, pedagogy, and content in teaching widely acknowledged as Technological, Pedagogical, and Content Knowledge (TPACK). It can be used to illustrate the teachers' knowledge in integrating technological knowledge, pedagogical knowledge, and content knowledge in authentic thinking procedures in designing instructional materials [18].

The ESP teachers' TPACK needs to be investigated to find out the best practice of BL implementation in teaching ESP. Accordingly, ESP teachers should have an understanding of integrating technology in their professional teaching. They also have to decide which activities between online and face-to-face meetings in order to encourage social interaction, monitoring of learning progress, and students' learning motivation [19]. Therefore, they have a role in facilitating students with appropriate instructional activities and apropos technologies for achieving learning goals. Consequently, this study aimed at, firstly, discerning ESP teachers' Technological Pedagogical and Content Knowledge (TPACK) in teaching English for the non-English department. 


\section{Technological Pedagogical and Content Knowledge (TPACK)}

TPACK is the knowledge which ESP teachers need to utilize the potential technology in a pedagogical environment" [3]. Therefore, it is viewed as a new direction in comprehending the multifarious interactions among learners, content, pedagogy, and technology in order to create a successful pedagogical process.

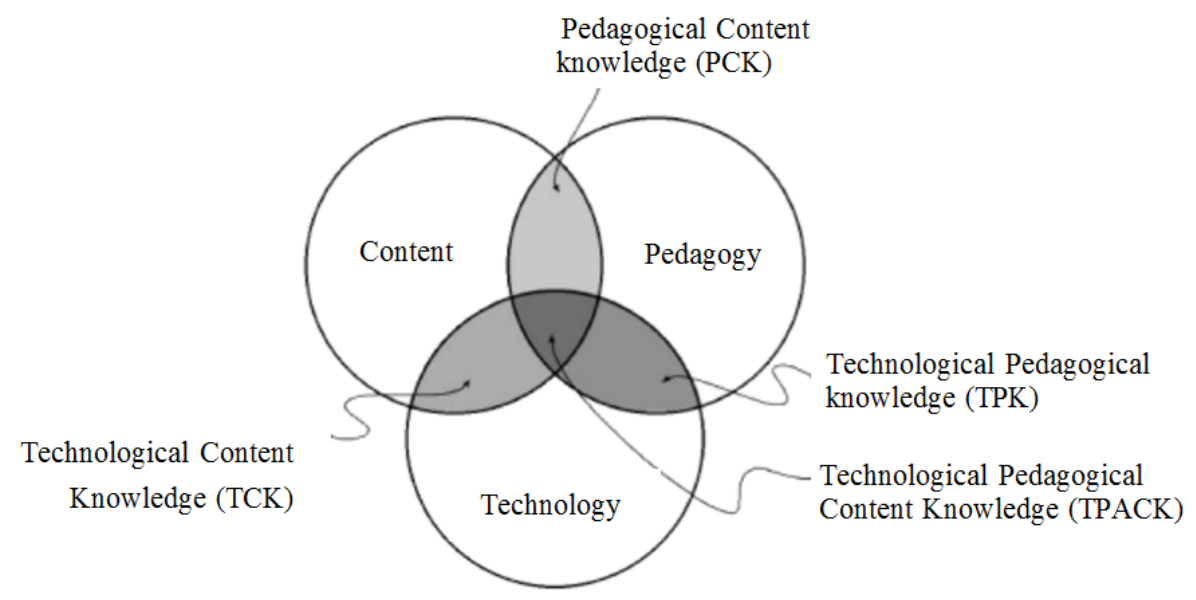

Fig. 1. TPACK framework [20]

TPACK framework stems from three main knowledge domains comprising 1) content knowledge (CK), pedagogical knowledge (PK), and Technology knowledge (TK). First, PK addresses teacher knowledge of any subject-matter for pedagogical purposes. Second, PK can be defined as an educator knowledge about instructional activities, strategies, as well as methods to enhance the learning process. Third, TK concerns teacher knowledge about the integration of technological facilities into learning design [21].

Furthermore, four domains of TPACK framework refers to the interaction of three main domains (CK, PK, TK). They are technological content knowledge (TCK), Technological Pedagogical Knowledge (TPK), pedagogical content knowledge (PCK), technological pedagogical and content knowledge (TPACK) [21]. TCK can be defined as the mutual relationship between technologies and learning contents [22]. TPK is teachers' knowledge or abilities to utilize multifarious technologies in teaching English for certain and professional knowledge [22]. Furthermore, PCK refers to the selection of effective teaching approaches to promote students to study instructional materials [20, 22, 23]. Meanwhile, TPACK can be defined as a teachers' knowledge of how particular technologies can be integrated with appropriate pedagogical methods in teaching certain materials [24]. 


\section{$3 \quad$ Methodology}

\subsection{Study design and participants}

The present study employed a survey research design based on a questionnaire. The participants in this study were 70 ESP teachers from 35 different higher institutions in Indonesia. The study was conducted from March to June 2019. All participants have taught ESP for nursing purposes and have applied the blended learning format in teaching ESP.

\subsection{Research instrument}

The questionnaire was administered using an online survey with a great deal of respect to participants' consent. It comprises two parts, i.e., ESP teachers' demographic information and their Technological Pedagogical and Content Knowledge (TPACK).

The first part of the questionnaire is a demographic survey question which was administered using four items related to ESP teachers' institution, gender, age, educational background, and length of teaching experience in ESP. The second one is about the rating scale question administering 28 items of ESP teachers' TPACK questionnaire modified from Bostancioğlu's \& Handley's study [3]. The questionnaire involved four subdomains out of seven TPACK subdomains [20] since the present study focused on exploring the integration among different TPACK knowledge, not individual knowledge. The TPACK domains comprise seven items of technological content knowledge (TCK), five items of pedagogical content knowledge (PCK), seven items of Technological Pedagogical Knowledge (TPK), and nine items of Technological Pedagogical and Content Knowledge (TPACK). It was composed using a Likert scale with five preferences, i.e., with five rating scale replies (strongly disagree, disagree, neither agree nor disagree, agree and strongly agree).

The questionnaire draft was tried out to 12 ESP teachers at Universitas Muhammadiyah Semarang in order to gauge the questionnaire validity and reliability. The validity was administered to analyze content validity and face validity having to do with the properness of questionnaire items toward the linguistic use, ESP materials, and trends in ESP instruction. Concurrently, they were asked to fill out the TPACK questionnaire draft to garner the statistical validity and reliability.

The statistical findings of TPACK questionnaire validity based on Pearson Correlations show that the statistical results of 28 questionnaire statements out of 33 items in which their significant scores were smaller than the values of 0.05 levels of significance, i.e., 28 valid items were employed in the present study. Meanwhile, the reliability coefficient of the TPACK questionnaire was gauged by internal consistency method in which the Cronbach's alphas of questionnaire scale was 0.79. In consequence, it was categorized at a good level [25]. It also indicated that the questionnaire has a high internal consistency [26] and satisfactory reliability. 


\subsection{Procedure}

The ESP teachers' questionnaire was distributed after obtaining the informed consent from each participant. They were ascertained that all data they filled out was confidential and employed, particularly for research purpose only. The participants filled out the questionnaire in the online form using Google Form with 15 to 20 minutes for completion. The participants were given a span of two weeks in responding to the questionnaire, so they had an adequate time to fill the survey out thoughtfully.

\subsection{Data analysis}

The data gathered from the demographic survey questions were tabulated and analyzed descriptively to describe the participants' age, gender, educational background, and length of their teaching experiences. Furthermore, the data from the second part of the questionnaire were gauged using the Statistical Package for the Social Sciences (SPSS) 21. The descriptive statistics were tabulated to enumerate the percentage of ESP teachers' preferences (Strongly disagree to agree strongly) in responding to the questionnaire. Subsequently, the accumulation of the agree and strongly agree preferences were illustrated in the form of graphics to figure out the degree of ESP teachers' TPACK in a blended learning context.

\section{$4 \quad$ Results and Discussion}

\subsection{Demographic information of ESP teachers}

The participants in this study were 70 ESP teachers from 35 different higher institutions in Indonesia. The data of demographic survey questions show the information about ESP teachers' gender, age, and length of teaching experience. The participants comprised 29 males and 41 females. In term of age, there were 5 ESP teachers aged 21-30 years, 47 ESP teachers aged 31-40 years, 16 ESP teachers aged 40-50 years, and 2 ESP teachers aged 51 years and above.

The data based on teaching experience were found that the majority of participants has 3-5 years of ESP teaching experience. Less than 20 percent of them has a relatively new experience in teaching (0-2 years). On the contrary, the small number of them who experience more than 16 years. The enumerated data of their teaching experience can be seen in Table 1 . 
Table 1. Teaching Experience of English for Specific Purposes (ESP)

\begin{tabular}{|l|c|c|}
\hline \multicolumn{1}{|c|}{ Teaching experience } & Frequency & Percentages \\
\hline $0-2$ years & 14 & $20 \%$ \\
\hline $3-5$ years & 24 & $34 \%$ \\
\hline $6-8$ years & 12 & $17 \%$ \\
\hline $9-11$ years & 12 & $17 \%$ \\
\hline $12-15$ years & 4 & $6 \%$ \\
\hline $16-19$ years & 1 & $1 \%$ \\
\hline$>20$ years & 3 & $4 \%$ \\
\hline
\end{tabular}

\subsection{Technological content knowledge (TCK) of ESP teachers}

The obtained data of ESP teachers' Technological Content Knowledge (TCK) concerning the utilization of technology for educational purposes can be seen in Table 2.

Table 2. The Frequencies of ESP Teachers' Technological Content Knowledge (TCK)

\begin{tabular}{|l|c|c|c|c|c|}
\hline $\begin{array}{l}\text { Questionnaire Statement (QS) (ESP teach- } \\
\text { ers' knowledge) }\end{array}$ & $\begin{array}{c}\text { Strongly } \\
\text { Disagree } \\
(\mathbf{\%})\end{array}$ & $\begin{array}{c}\text { Disagree } \\
\mathbf{( \% )}\end{array}$ & $\begin{array}{c}\text { Uncertain } \\
\mathbf{( \% )}\end{array}$ & $\begin{array}{c}\text { Agree } \\
\mathbf{( \% )}\end{array}$ & $\begin{array}{c}\text { Strongly } \\
\text { Agree } \\
\mathbf{( \% )}\end{array}$ \\
\hline $\begin{array}{l}\text { Technologies for Teaching Listening in ESP } \\
\text { Classroom }\end{array}$ & 4.3 & 5.7 & 10 & 54.3 & 25.7 \\
\hline $\begin{array}{l}\text { Technologies for Teaching Speaking in ESP } \\
\text { Classroom }\end{array}$ & 2.9 & 10.0 & 15.7 & 60.0 & 11.4 \\
\hline $\begin{array}{l}\text { Technologies for Teaching Reading in ESP } \\
\text { Classroom }\end{array}$ & 1.4 & 5.7 & 2.9 & 65.7 & 24.3 \\
\hline $\begin{array}{l}\text { Technologies for Teaching Writing in ESP } \\
\text { Classroom }\end{array}$ & 8.6 & 18.6 & 14.3 & 55.7 & 2.9 \\
\hline $\begin{array}{l}\text { Technologies for Teaching English Grammar } \\
\text { in ESP Classroom }\end{array}$ & 8 & 11.4 & 25.7 & 51.4 & 3.5 \\
\hline $\begin{array}{l}\text { Technologies for Teaching English vocabu- } \\
\text { lary in ESP Classroom }\end{array}$ & 4.3 & 7.1 & 15.7 & 50.0 & 22.9 \\
\hline $\begin{array}{l}\text { Technologies for Teaching Pronunciation in } \\
\text { ESP Classroom }\end{array}$ & 2.9 & 15.7 & 11.4 & 60.0 & 10.0 \\
\hline
\end{tabular}

Table 2 elucidates frequencies of ESP teachers' Technological Content Knowledge (TCK) in which $90 \%$ of them, the highest percentage, recognize technologies that can be used in preparing ESP reading materials. Afterward, recognition of technologies for teaching listening class play the second most percentage, which $80 \%$ of them was agreed. The knowledge about technologies for teaching vocabulary, speaking, and pronunciation have somewhat similar percentages of the agreement score, $75 \%, 72 \%$, and $70 \%$ respectively. The analysis results show that the technologies in teaching reading materials and listening sources are very familiar with ENP teachers. It means that utilizing technological tools like the internet; receptive language skills are more authentic and multifarious. The previous study concurs the present findings that the teachers have realized various technologies for certain skills based on educational needs [27]. 
In contrast, the term of ESP teachers' knowledge about technologies in teaching writing skill and English language grammar was relatively low (58.6 and 54.9, respectively) in which the percentages of their uncertainty concerning both writing knowledge and grammar knowledge are relatively high. It is in line with the study applying TPACK in writing instruction for student nurses in a Taiwan University that ENP teachers tend to avoid online writing class since leaners felt less content with the writing instruction because the assignment of writing activities outside the classroom make them pressured [28]. Hence, ENP teachers should have more training and references more germane to the attractive and engaging Technology Enhanced Language Learning applications and websites for teaching grammar and writing skills.

\subsection{Pedagogical content knowledge (PCK) of ESP teachers}

Pedagogical Content Knowledge (PCK) is the knowledge by the applicability of the pedagogical approach and learning materials. It refers to understand what kinds of teaching approaches concurs with the learning content for a finer pedagogical process [29]. The Percentages of ESP teachers' PCK was enumerated in Table 3.

Table 3. The Frequencies of ESP Teachers' Pedagogical Content Knowledge (PCK

\begin{tabular}{|l|c|c|c|c|c|}
\hline \multicolumn{1}{|c|}{$\begin{array}{c}\text { Questionnaire Statement (QS) (ESP } \\
\text { Teachers' Abilities) }\end{array}$} & $\begin{array}{c}\text { Strongly } \\
\text { Disagree } \\
(\boldsymbol{\%})\end{array}$ & Disagree (\%) & $\begin{array}{c}\text { Uncertain } \\
(\%)\end{array}$ & $\begin{array}{c}\text { Agree } \\
(\boldsymbol{\%})\end{array}$ & $\begin{array}{c}\text { Strongly } \\
\text { Agree } \\
(\%)\end{array}$ \\
\hline $\begin{array}{l}\text { Delivering appropriate feedback on } \\
\text { learners' language aspects }\end{array}$ & 2.5 & 16.1 & 31.4 & 38.6 & 11.4 \\
\hline $\begin{array}{l}\text { Providing target language input at an ap- } \\
\text { propriate level of students' proficiency }\end{array}$ & 3.0 & 11.2 & 25.8 & 51.4 & 8.6 \\
\hline $\begin{array}{l}\text { Selecting authentic resources to suit student } \\
\text { needs }\end{array}$ & 2.3 & 15.7 & 12.0 & 60.0 & 10.0 \\
\hline $\begin{array}{l}\text { Deciding an appropriate approach to teach } \\
\text { ESP learners }\end{array}$ & 2.9 & 11.4 & 25.7 & 51.4 & 8.6 \\
\hline $\begin{array}{l}\text { Identifying linguistic problems encountered } \\
\text { by ESP learners (i.e. phonological, lexical } \\
\text { or grammatical problems) }\end{array}$ & 2.9 & 15.7 & 11.4 & 60.0 & 10.0 \\
\hline
\end{tabular}

ENP Teachers' Pedagogical Content Knowledge (PCK), as shown in Table 3, was identified from five abilities. $70 \%$ of ENP teachers can select authentic resources to suit student needs such as listening to English news, watching English videos from YouTube and identify linguistic problems encountered by ESP learners related to phonological, lexical or grammatical problems. Since pedagogy and knowledge cannot be separated in teaching and learning process [27], ENP teachers' ability to choose the apropos learning sources and recognize linguistic problems should be enhanced for developing a professional-pedagogical practice to compensate the lack of content.

Deciding an appropriate approach for teaching ESP learners and providing target language input at an appropriate level of students' proficiency were experienced by $60 \%$ of them, while a quarter of them was ambivalent about the abilities. Unfortunately, only half of them can deliver appropriate feedback on learners' language aspects in 
which $31.5 \%$ of them were still uncertain about their feedback, whether it is appropriate or not. ENP teachers' PCK need to be improved because somewhat low percentages form every item. Therefore, the ENP teachers have to master both language pedagogy and language contents to eradicate the gaps and challenges generally higher education students encountered in mastering English [30]. Indeed, to promote peer review activities and give feedback on time were two major challenges during developing an online English writing course for nursing students [28].

\subsection{Technological pedagogical knowledge (TPK) of ESP teachers}

Integrating technology in enhancing learning with particular pedagogical decisions is the basis for professional advancement in twenty-first-century learning [31]. The particular ESP teachers' knowledge about technology integration in pedagogy is familiar with Technological Pedagogical Knowledge (TPK) which is teachers' knowledge or abilities to utilize multifarious technologies in teaching English for certain and professional knowledge. The TPK profile results of ESP teachers is demonstrated in Table 4.

The descriptive data in Table 4 indicates the percentages of ESP teachers in enacting TPK. It indicates that they were able to integrate their technological ability into their teaching activities. In detail, data shows that most teachers (89\%) could engage their learners in coping with authentic problems using digital resources. The authentic problems using digital resources can be manifested in student-centered learning, i.e., learners actively explore learning materials, do authentic tasks, and create effectual communication between individual and groups by doing experimentation and action simultaneously [32,33]. With technological supports such as the internet, learners can look for fast the authentic learning model and practice the real-world dialogue with global partners. The learning process can be contextualized by authentically replicated real-world work through the same tools and resources used by many professionals and artisans [34].

The second highest percentages of ESP teachers' TPK are related to adapting the use of technologies in different teaching activities. Interestingly, almost equal percentages of them ( $77 \%$ and 76 respectively) could design relevant learning experiences to promote student learning and select technologies for learning assessment. The recent case study of ESL teachers from three different schools in Malaysia seems to corroborate the related findings that integrating technology in mastering English can promote learners to explore English literature actively [35]. 
Table 4. The Frequencies of ESP Teachers' Technological Pedagogical Knowledge (TPK)

\begin{tabular}{|l|c|c|c|c|c|}
\hline \multicolumn{1}{|c|}{$\begin{array}{c}\text { Questionnaire Statement (QS) (ESP } \\
\text { Teachers' Abilities) }\end{array}$} & $\begin{array}{c}\text { Strongly } \\
\text { disagree } \\
(\boldsymbol{\%})\end{array}$ & $\begin{array}{c}\text { Disagree } \\
(\mathbf{\%})\end{array}$ & $\begin{array}{c}\text { Uncertain } \\
(\%)\end{array}$ & $\begin{array}{c}\text { Agree } \\
(\mathbf{\%})\end{array}$ & $\begin{array}{c}\text { Strongly } \\
\text { Agree } \\
(\%)\end{array}$ \\
\hline $\begin{array}{l}\text { Evaluating the appropriateness of } \\
\text { technologies for teaching }\end{array}$ & 11.4 & 10.0 & 15.7 & 60.0 & 2.9 \\
\hline $\begin{array}{l}\text { Choosing technologies that enhance the } \\
\text { teaching } \\
\text { approaches for a lesson }\end{array}$ & 1.4 & 17.1 & 15.7 & 55.7 & 10.0 \\
\hline $\begin{array}{l}\text { Choosing technologies for learning } \\
\text { assessment }\end{array}$ & 4.3 & 4.3 & 14.3 & 52.9 & 24.3 \\
\hline $\begin{array}{l}\text { Thinking critically about how to utilize } \\
\text { technology in ESP classroom }\end{array}$ & 2.9 & 11.4 & 25.7 & 51.4 & 8.6 \\
\hline $\begin{array}{l}\text { Adapting the use of the technologies in } \\
\text { different teaching activities }\end{array}$ & 4.3 & 5.7 & 10.0 & 54.3 & 25.7 \\
\hline $\begin{array}{l}\text { Designing relevant learning experiences to } \\
\text { promote student learning integrating tech- } \\
\text { nology }\end{array}$ & 4.3 & 4.3 & 14.3 & 52.9 & 24.3 \\
\hline $\begin{array}{l}\text { Engaging students in coping with authentic } \\
\text { problems using digital resources }\end{array}$ & 1.4 & 7.1 & 2.9 & 65.7 & 22.9 \\
\hline
\end{tabular}

However, the ESP teachers' ability to think critically about how to use technology in ESP classroom, select appropriate technologies for enhancing the teaching approach, and evaluate the appropriateness of technologies for teaching were experienced by somewhat low percentages of ENP teachers $(60 \%, 62,9 \%$, and $65 \%$ respectively). In consequence, ENP teachers need to develop their critical thinking of technology utilization because some technological programs or software are not developed specifically for pedagogical aims [18]. They have to select which technology specification and features that suit in learning activities. It is also corroborated with the previous study that educators should have an adequate understanding of multifarious pedagogical methods and technological tools [36].

\subsection{Technological pedagogical and content knowledge (TPACK) of ESP teachers}

Technological Pedagogical and Content Knowledge (TPACK) is a comprehensive pedagogical framework advanced currently by educational researchers in developing technology-enhanced learning [37]. It has been adapted in English instruction by educational researchers and was applied appreciably in the literature to combine content, pedagogy, and technology [31]. Thus, discerning ENP teachers' TPACK can be used to illustrate the teachers' knowledge in integrating among technological knowledge, pedagogical knowledge, and content knowledge in authentic thinking procedures in designing instructional materials [18]. The results of ESP teachers' TPACK profile can be seen in Table 5.

Taking the statistical data into account in Table 5, most ESP teachers (92\%) have participated in digital learning communities to explore creative technological applications for pedagogical activities. It is consistent with the previous study that exploring TPACK elucidated the teachers' knowledge in integrating among technological 
knowledge, pedagogical knowledge, and content knowledge in developing authentic thinking procedures in designing instructional materials [18]. ESP teachers' TPACK could promote the activities such evaluation of learning multimedia, lesson designs, discussion activity, and learning reflections [29]. It is also supported by a study that the integration of ICT in language learning is effective to impart authentic materials to students [38].

Utilizing a range of technologies have a positive effect on students' learning engagement. $82 \%$ of them believed that emerging technologies in language classroom enable students to become active participants. Besides, interestingly, the same percentages of ESP teachers $(80 \%)$ could utilize a range of technologies facilitating students to pursue their curiosities and provide equitable access to digital language learning tools and resources. The present positive aspects were corroborated by some studies that technology integration manifested in a blended learning environment allowed students to expedite the active learning process [2].

Table 5. The Frequencies of ESP Teachers' Technological Pedagogical and Content Knowledge (TPACK)

\begin{tabular}{|c|c|c|c|c|c|}
\hline $\begin{array}{c}\text { Questionnaire Statements (QS) (ESP } \\
\text { Teachers' Abilities) }\end{array}$ & $\begin{array}{c}\text { Strongly } \\
\text { Disagree }(\%)\end{array}$ & $\begin{array}{l}\text { Disagree } \\
\quad(\%)\end{array}$ & Uncertain (\%) & $\begin{array}{l}\text { Agree } \\
(\%)\end{array}$ & \begin{tabular}{|c|} 
Strongly \\
Agree \\
$(\%)$ \\
\end{tabular} \\
\hline $\begin{array}{l}\text { Combining English linguistic concepts, } \\
\text { technologies, and teaching approaches }\end{array}$ & 4.3 & 4.3 & 14.3 & 50.0 & 27.1 \\
\hline $\begin{array}{l}\text { Selecting appropriate technologies that } \\
\text { combine English culture, technologies, } \\
\text { and teaching approaches }\end{array}$ & 4.3 & 5.7 & 10.0 & 54.3 & 25.7 \\
\hline $\begin{array}{l}\text { Selecting technologies to enhance what } \\
\text { ESP teacher teach, how ESP teach, and } \\
\text { what learners learn }\end{array}$ & 4.3 & 4.3 & 14.3 & 52.9 & 24.3 \\
\hline $\begin{array}{l}\text { Utilizing technologies effectively to } \\
\text { communicate relevant information }\end{array}$ & 2.9 & 11.4 & 25.7 & 51.4 & 8.6 \\
\hline $\begin{array}{l}\text { Utilizing a range of technologies } \\
\text { facilitating students to pursue their } \\
\text { curiosities }\end{array}$ & 1.4 & 5.7 & 10.0 & 60.0 & 22.9 \\
\hline $\begin{array}{l}\text { Utilizing a range of technologies that } \\
\text { enable students to become active } \\
\text { participants }\end{array}$ & 2.9 & 5.7 & 11.4 & 65.7 & 14.3 \\
\hline $\begin{array}{l}\text { Providing equitable access to digital } \\
\text { language learning tools and resources }\end{array}$ & 3.2 & 4.3 & 9.7 & 60.0 & 22.9 \\
\hline $\begin{array}{l}\text { Facilitating intercultural understanding } \\
\text { using technology to engage students in } \\
\text { different cultures }\end{array}$ & 2.9 & 11.4 & 25.7 & 51.4 & 8.6 \\
\hline $\begin{array}{l}\text { Participating in digital learning } \\
\text { communities to explore creative } \\
\text { technological applications for teaching }\end{array}$ & 1.4 & 4.3 & 2.9 & 65.7 & 25.7 \\
\hline
\end{tabular}

Three items of TPACK have similar percentages. They are selecting appropriate technologies that combine English culture, technologies, and teaching approaches. Second, combining English linguistic concepts, technologies, and teaching approaches, and selecting technologies to enhance what ESP teacher teach. It is in line with the 
previous article that technology-enhanced learning in a blended learning context can create mixed modalities in teaching [14].

However, relatively lower percentages of ENP teachers' TPACK deals with facilitating intercultural understanding using technology to engage students in different cultures and utilizing technologies effectively to communicate relevant information. Intercultural understanding and communication should be facilitated by allowing language students to explore and use various technological applications such as incorporating reflective blogging, video activities, and practical practice using mobile devices [39].

\subsection{The differences in mean scores among ESP Teachers' TPACK subdomains}

The descriptive results, as illustrated in Figure 1, show the comparison of average scores based on mean scores among of questionnaire items in four subdomains of ESP teachers' TPACK.

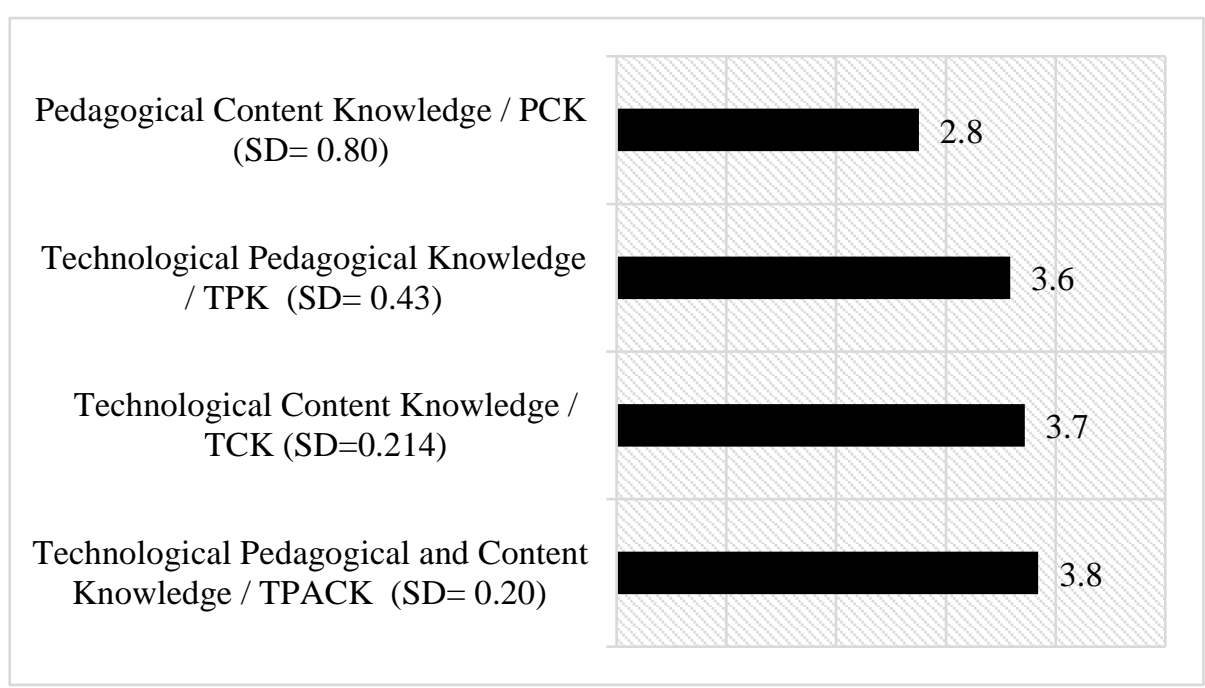

SD: Standard Deviation

Fig. 2. The mean scores of ESP teachers' TPACK subdomains

The finding (Figure 1) explicates that the means scores of ESP teachers' knowledge combining technology, pedagogy, and content were categorized into four domains comprising PCK, TPK, TCK, and TPACK. The combination of dealing with technology aspects was relatively high in which the highest score was related to their TPACK. Subsequently, their TCK was the second-highest mean score, and their TPK was the third one. A good means scores for three domain of ESP teachers' TPACK might be influenced by their age in which the majority of them (52 out of 70) aged less than 40 years old. It is in line with the finding of previous research that young 
teachers were more interested in technology for teaching [21]. It means the younger ESP teachers are more familiar with technology integration. They are prone to use mobile mode of instruction to supplement the lesson design because students could learn the materials easily [40]. In contrast, the older users intended to avoid the new technological application because of difficult perception toward utilizing it in teaching [41].

However, the mean score of the integration between pedagogy and content knowledge (PCK) was low, with 2.8 (SD: 0.80) out of 5 as the maximum score. It means that the majority of ESP teachers need to improve their pedagogical and content knowledge. It could be impacted by various factors such as the length of teaching experience and educational background. The most ESP teachers $(71 \%)$ had less than eight years of teaching experience. It is corroborated with the previous study that the teachers who had more than ten years of teaching experience had better PCK [27]. It means that having less teaching experience influence on ESP teachers' low pedagogical knowledge and content knowledge. Another factor influencing the low pedagogical content knowledge is most ESP teachers' education background are language teachers (56 out of 70) in which generally they have some challenges to comprehend real needs of ESP context. Therefore, language teachers and content teachers should collaborate to design and conduct ESP instruction to meet ESP students' disciplinerelated needs in real-world works [42]. Besides, the skills of integrating technology with pedagogy befitting the subject-content were still lack [43].

\section{Conclusion}

The present study has found four TPACK domains of ESP teachers.

First, most ESP teachers have been qualified with TCK involving technologies for teaching reading and speaking skills. However, they need to engage the way of teaching writing skill activities and English language grammar integrated with technology. Second, regarding PCK of ESP teachers, ESP teachers were required to improve their ability to choose the germane learning sources, recognize linguistic problems, and give appropriate feedback on learners' language aspects.

Third, concerning ESP teachers' TPK, the integration of technology into their instructional activities was experienced by most ESP teachers, but some of them had challenges to evaluate the appropriateness of technologies for teaching. Finally, the most ESP teachers, in general, had a better knowledge of TPACK domain appertaining to technology, pedagogy, and content knowledge integration, but the technology utilization for facilitating intercultural understanding to communicate relevant information effectively need to be enhanced.

Further research is needed to empower appropriate technologies in facilitating learners to master writing skill and grammar knowledge. Moreover, the collaboration between general English language teachers and content teachers who comprehend specific purposes of discipline field and professional communities is required to enhance ESP teachers' PCK in successfully teaching English for nursing purposes. 


\section{Acknowledgement}

The authors are very grateful to the Ministry of Research, Technology, and Higher Education of the Republic of Indonesia for giving financial support to conduct the present study.

\section{$7 \quad$ References}

[1] M. Sherkatolabbasi and A. Mahdavi-Zafarghandi, "Evaluation of ESP Teachers in Different Contexts of Iranian Universities," Int. J. Appl. Linguist. English Lit., vol. 1, no. 2, pp. 198-205, 2012. https://doi.org/10.7575/ijalel.v.1n.2p.198

[2] S. Wichadee, "A Development of the Blended Learning Model Using Edmodo for Maximizing Students' Oral Proficiency and Motivation,” Int. J. Emerg. Technol. Learn., vol. 12, no. 2, pp. 137-154, 2017. https://doi.org/10.3991/ijet.v12i02.6324

[3] A. Bostancioğlu and Z. Handley, "Developing and validating a questionnaire for evaluating the EFL 'Total PACKage': Technological Pedagogical Content Knowledge (TPACK) for English as a Foreign Language (EFL),” Comput. Assist. Lang. Learn., vol. 8221, no. January, pp. 1-27, 2018. https://doi.org/10.1080/09588221.2017.1422524

[4] A. Meydanlioglu and F. Arikan, "Hybrid learning in higher education," Int. J. Inf. Commun. Engine ering, vol. 8, no. 5, pp. 1292-1295, 2014.

[5] N. Aeni, T. Prihatin, and Y. Utanto, "Pengembangan Model Blended Learning Berbasis Masalah pada Mata Pelajaran Sistem Komputer," Innov. J. Curric. Educ. Technol., vol. 6, no. 2, pp. 84-97, 2017.

[6] D. R. Garrison and N. D. Vaughan, Blended Learning in Higher Education. USA: JohnWiley \& Sons, Inc., 2008.

[7] D. Lalima and K. L. Dangwal, "Blended Learning: An Innovative Approach,” Univers. J. Educ. Res., vol. 5, no. 1, pp. 129-136, 2017.

[8] K. F. Hew and W. S. Cheung, Using Blended Learning: Evidence-Based Practices. New York: SpringerBriefs in Education, 2014.

[9] R. Birbal, M. Ramdass, and C. Harripaul, "Student Teachers' Attitudes towards Blended Learning,” J. Educ. Hum. Dev., vol. 7, no. 2, pp. 9-26, 2018. https://doi.org/10.15640/je hd.v7n2a2

[10] K. C. Li, "Encountering pedagogical challenges: a case of three pilot blended learning courses,” Int. J. Innov. Learn., vol. 13, no. 2, p. 153, 2013.

[11] J. W. L. Keogh, L. Gowthorp, and M. McLean, "Perceptions of sport science students on the potential applications and limitations of blended learning in their education: a qualitative study," Sport. Biomech., vol. 16, no. 3, pp. 297-312, 2017. https://doi.org/10.10 $\underline{80 / 14763141.2017 .1305439}$

[12] A. Ma Pinto-Llorente, M. Cruz S Anchez-G Omez B, F. Jos E García-Pe, Nalvo, and S. Casillas-Martín, "Students\&\#x2019; perceptions and attitudes towards asynchronous technological tools in blended-learning training to improve grammatical competence in English as a second language," Comput. Human Behav., 2016. https://doi.org/10.1016/j.ch b.2016.05.071

[13] N. P. Napier, S. Dekhane, S. Smith, and G. G. College, "Transitioning to Blended Learning: Understanding Student and Faculty Perceptions," J. Asynchronous Learn. Networks, vol. 15, no. 1, pp. 20-32, 2006. https://doi.org/10.24059/olj.v15i1.188 
[14] M. A. Naaj, M. Nachouki, and A. Ankit, "Evaluating Student Satisfaction with Blended Learning in a Gender-Segregated Environment," J. Inf. Technol. Educ. Res., vol. 11, no. 1, pp. 185-200, 2012. https://doi.org/10.28945/1692

[15] E. Monteiro and K. Morrison, "Challenges for collaborative blended learning in undergraduate students,” Educ. Res. Eval., vol. 20, no. January 2015, pp. 564-591, 2014.

[16] U. Ocepek, Z. Bosnić, I. Nančovska Šerbec, and J. Rugelj, "Exploring the relation between learning style models and preferred multimedia types," Comput. Educ., vol. 69, pp. 343355, 2013. https://doi.org/10.1016/j.compedu.2013.07.029

[17] C. Whittaker, "Introduction to Blended Learning," in Blended Learning in English Language Teaching: Course Design and Implementation, London: British Council, 2013.

[18] J. J. Tseng, Y. S. Cheng, and H. N. Yeh, "How pre-service English teachers enact TPACK in the context of web-conferencing teaching: A design thinking approach," Comput. Educ., vol. 128, no. September 2018, pp. 171-182, 2019. https://doi.org/10.1016/j.compedu.2018. $\underline{09.022}$

[19] R. Boelens, B. De Wever, and M. Voet, "Four key challenges to the design of blended learning: A systematic literature review," Educ. Res. Rev., vol. 22, pp. 1-18, 2017. https:// doi.org/10.1016/j.edurev.2017.06.001

[20] Koehler \& Mishra, "Technological Pedagogical Content Knowledge: A Framework for Teacher Knowledge,” Teach. Coll. Rec., vol. 108, no. 6, pp. 1017-1054, 2006. https://doi. org/10.1111/j.1467-9620.2006.00684.x

[21] I. Y. Kazu and P. Erten, "Teachers' Technological Pedagogical Content Knowledge SelfEfficacies,” J. Educ. Train. Stud., vol. 2, no. 2, pp. 126-144, 2014. https://doi.org/10.1111 4/jets.v2i2.261

[22] M. J. Koehler, P. Mishra, K. Kereluik, T. S. Shin, and C. R. Graham, "The Technological Pedagogical Content Knowledge Framework," in Handbook of Research on Educational Communications and Technology: Springer Science+Business Media New, 2014. https:// doi.org/10.1007/978-1-4614-3185-5_9

[23] P. Hubber and E. Loong, "Increasing Learner Engagement of Learning Technologies and Science TPACK through Representational Challenges," in Increasing Learner Engagement of Learning Technologies and Science TPACK through Representational Challenges: WEB 2.0 and Blended Learning Technologies, C. Wankel, P. Blessinger, J. Stanaityte, and N. Washington, Eds. UK: Emerald Group Publishing Limited, 2013. https://doi.org/10.11 $\underline{08 / \mathrm{s} 2044-9968(2013) 000006 \mathrm{~g} 006}$

[24] J. J. Tseng, "Exploring TPACK-SLA interface: insights from the computer-enhanced classroom," Comput. Assist. Lang. Learn., vol. 31, no. 4, pp. 390-412, 2018. https://doi.o rg/10.1080/09588221.2017.1412324

[25] R. . DeVellis, Scale development: Theory and applications. California: Sage, 2012.

[26] R. Ho, Multivariate Data Analysis with IBM SPSS, 2nd ed. Boca Raton, London, New York: Taylor \& Francis Group, LLC, 2014.

[27] M. Mahdum, "Technological Pedagogical and Content Knowledge (TPACK) of English Teachers in Pekanbaru, Riau, Indonesia," Mediterr. J. Soc. Sci., vol. 6, no. 5, pp. 168-176, 2015. https://doi.org/10.5901/mjss.2015.v6n5s1p168

[28] H. C. Tai, M. Y. Pan, and B. O. Lee, "Applying Technological Pedagogical and Content Knowledge (TPACK) model to develop an online English writing course for nursing students," Nurse Educ. Today, vol. 35, no. 6, pp. 782-788, 2015. https://doi.org/10.1016/j. nedt.2015.02.016

[29] C. W. Chien, "Analysis of Taiwanese undergraduates' learning and development of TPCK in English instruction,” Int. J. Teach. Case Stud., vol. 6, no. 3, p. 212, 2015. 
[30] S. Rukmini, "Content-based language learning and communicative approach to English language teaching for technology and management courses: Integration and implications," IUP J. English Stud., vol. 12, no. 4, pp. 84-88, 2017.

[31] S. N. K. Benson, C. L. Ward, and X. Liang, "The Essential Role of Pedagogical Knowledge in Technology Integration for Transformative Teaching and Learning," in Technological Pedagogical Content Knowledge: Exploring, Developing, and Assessing TPCK, C. Angeli and N. Valanides, Eds. New York: Springer Science+Business Media, 2015. https://doi.org/10.1007/978-1-4899-8080-9_1

[32] H. S. Barrows and L. W. K. N, Principles and Practice of authentic Problem-based Learning. Singapore: Pearson Education South Asia, 2007.

[33] M. M. Lombardi and D. G. Oblinger, "Authentic Learning for the 21st Century: An Overview,” Educ. Learn. Initiat., vol. 1, no. May, pp. 1-12, 2007.

[34] J. Brand, 1-to-1 at Home: A Parent's Guide to School-Issued Laptops and Tablets, 1st ed. USA: HomePage Books, 2013.

[35] A. Zainal, "ESL teachers' use of ICT in teaching English literature: An analysis of teachers' TPCK," Procedia - Soc. Behav. Sci., vol. 34, pp. 234-237, 2012. https://doi.org/ 10.1016/j.sbspro.2012.02.047

[36] M. Bower and P. Vlachopoulos, "A critical analysis of technology-enhanced learning design frameworks,” Br. J. Educ. Technol., vol. 49, no. 6, pp. 981-997, 2018. https://doi. org/10.1111/bjet.12668

[37] N. Vaughan, "Student Engagement and Blended Learning: Making the Assessment Connection," Educ. Sci., vol. 4, no. 4, pp. 247-264, 2014.

[38] by Asnawi Muslem, Y. Qismullah Yusuf, and R. Juliana, "Perceptions and Barriers To ICT Use Among English Teachers in Indonesia," Teach. English with Technol., vol. 18, no. 1, pp. 3-23, 2018.

[39] J. M. Perren, "Intercultural Communication Through Technology," The TESOL Encyclopedia of English Language Teaching. John Wiley \& Sons, Inc, pp. 1-7, 2018.

[40] [40] M. A. Batsila, C. A. Tsihouridis, and A. H. Tsihouridis, “" All for One and One for All ' - Creating a Mobile Learning Net for ESP Students ' Needs," Int. J. Emerg. Technol. Learn., vol. 12, no. 4, pp. 17-38, 2017. https://doi.org/10.3991/ijet.v12i04.6428

[41] C. Lee, A. S. Yeung, and T. Ip, "Use of computer technology for English language learning: do learning styles, gender, and age matter?," Comput. Assist. Lang. Learn., vol. 29, no. 5, pp. 1033-1049, 2016. https://doi.org/10.1080/09588221.2016.1140655

[42] E. Arnó-Macià and G. Mancho-Barés, "The role of content and language in content and language integrated learning (CLIL) at university: Challenges and implications for ESP," English Specif. Purp., vol. 37, no. 1, pp. 63-73, 2015. https://doi.org/10.1016/j.esp.2014.0 $\underline{6.007}$

[43] S. A. Garba, Y. Byabazaire, and A. H. Busthami, "Toward the Use of 21 st Century Teaching-Learning Approaches: The Trend of Development in Malaysian Schools within the Context of Asia Pacific,” Int. J. Emerg. Technol. Learn., vol. 10, no. 4, pp. 72-79, 2015. https://doi.org/10.3991/ijet.v10i4.4717

\section{Authors}

Dr. Dodi Mulyadi, M.Pd has been a lecturer at Universitas Muhammadiyah Semarang since 2010 and his research interests comprise ELT, Listening Strategies, Technology Enhanced Language Learning (TELL), and ESP. He has presented and published some articles on journals and conferences. He is also an editor for journals 
(LENSA and Journal of English Teaching and Learning Issues). He is a member of TEFLIN (Teaching English as Foreign Language Indonesia) and ASIA TEFL.

Testiana Deni Wijayatingsih, M.Pd is a lecturer at Universitas Muhammadiyah Semarang, Indonesia. She got her postgraduate studies in 2010 from State University of Semarang. She is interested in ELT, TELL. She is a member of TEFLIN and ASIA TEFL. She has presented articles in Journal article and conference proceedings.

Riana Eka Budiastuti, M.Pd is a lecturer at Universitas Muhammadiyah Semarang. She is so much interested in research in the area of Mobile Assisted Language Learning and English for Young Learner. She is a member of TEFLIN and ASIA TEFL. She has presented articles in Journal article and conference proceedings.

Siti Aimah, M.Pd is a lecturer at, Universitas Muhammadiyah Semarang. Her interest is Teaching English as a Foreign Language (TEFL), especially for pedagogical studies. He is also an editor for LENSA journal and a member of TEFLIN (Teaching English as Foreign Language Indonesia).

Muhimatul Ifadah, M.Pd is a lecturer at Universitas Muhammadiyah Semarang, Indonesia. She is interested in English assessment and psychological approach in teaching. He is also an editor for LENSA journal and a member of TEFLIN (Teaching English as Foreign Language Indonesia).

Article submitted 2019-08-10. Resubmitted 2020-01-06. Final acceptance 2020-01-20. Final version published as submitted by the authors. 